\title{
KANTOROVICH TYPE REVERSE INEQUALITIES FOR OPERATOR NORM
}

\author{
Jun ICHI FuJII, YuKI SEO AND MASARU TOMINAGA
}

Abstract. In this paper, we shall extend Bourin's theorem for unitarily invariant norm in the framework of operator theory on a Hilbert space by applying the Mond-Pečarić method for convex functions. Moreover we obtain the operator norm version. Among others, we show that if $A$ and $Z$ are positive operators on a Hilbert space $H$ such that $0<m I \leqslant Z \leqslant M I$ for some scalars $0<m<M$, then for each $\alpha>0$

$$
\left\|\left(A Z^{p} A\right)^{\frac{1}{p}}\right\| \leqslant \alpha r\left(Z A^{\frac{2}{p}}\right)+\beta(m, M, p, \alpha)\|A\|^{\frac{2}{p}} \quad \text { for all } p>1
$$

for some suitable constant $\beta(m, M, p, \alpha)$, where $\|\cdot\|$ is the operator norm and $r(\cdot)$ is the spectral radius.

Mathematics subject classification (2000): 47A30, 47A63.

Key words and phrases: Kantorovich inequality, operator inequality, spectral radius, operator norm, Kantorovich constant.

\section{REFERENCES}

11] H. ARAKI, On an inequality of Lieb and Thirring, Letters in Math. Phys., 19 (1990), 167-170.

[2] R. BHATIA, Matrix Analysis, Springer, New York, 1997.

[3] J.-C. Bourin, Compressions, Dilations and Matrix inequalities, Monographs in Research Group in Math, Inequal. and Appl., 2004.

[4] J. I. FujII, M. FujII, Y. Seo And M. Tominaga, On generalized Kantorovich inequalities, Proc. Int. Sym. on Banach and Function Spaces, Kitakyushu, Japan, October 2-4, (2003), 205-213.

[5] M. FujII, S. Izumino, R. NAKAMOto And Y. SEO, Operator inequalities related to Cauchy-Schwarz and Hölder-McCarthy inequalities, Nihonkai Math. J., 8 (1997), 117-122.

[6] T. FuRUTA, Invitation to Linear Operators, Taylor and Francis, London and New York, 2001.

[7] T. FURUTA, Specht ratio $S(1)$ can be expressed by Kantorovich constant $K(p): S(1)=\exp K^{\prime}(1)$ and its application, Math. Inequal. Appl., 6, 3 (2003), 521-530.

[8] W. GReUB AND W. RheInBOLDT, On a generalization of an inequality of L. V. Kantorovich, Proc. Amer. Math. Soc., 10 (1959), 407-415.

[9] J. Mićić, Y. SEO, S.-E. TAKAHASI AND M. TOMINAGA, Inequalities of Furuta and Mond-Pečarić, Math. Inequal. Appl., 2, 1 (1999), 83-111.

[10] B. Mond And J. E. PeČArić, Convex inequalities in Hilbert space, Houston J. Math., 19, (1993), 405-420.

[11] M. NAKAMURA, A remark on a paper of Greub and Rheiboldt, Proc. Japan Acad., 36, (1960), $198-199$.

[12] J. E. PeČArić, T. Furuta, J. Mićić AND Y. SEO, Mond-Pečarić Method in Operator Inequalities 1 , Element, Zagreb, 2005.

[13] M. Tominaga, Reverse Estimations of Operator Inequalities with Convexity, Thesis, 2002.

[14] T. YAMAZAKI, An extension of Specht's theorem via Kantorovich inequality and related results, Math. Inequal. Appl. 3, 1 (2000), 89-96. 